\title{
Peripheral and Central Mechanisms Involved in the Hormonal Control of Male and Female Reproduction
}

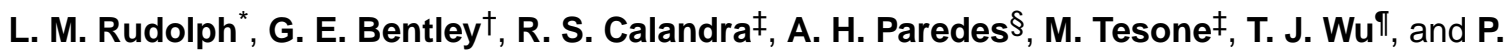 \\ E. Micevych ${ }^{*}$ \\ 'Department of Neurobiology, Laboratory of Neuroendocrinology, David Geffen School of \\ Medicine at UCLA, Los Angeles, CA, USA. \\ tDepartment of Integrative Biology, and Helen Wills Neuroscience Institute, University of \\ California, Berkeley, Berkeley, CA, USA. \\ ‡Instituto de Biología y Medicina Experimental (IBYME-CONICET), Buenos Aires, Argentina. \\ $\S$ Laboratory of Neurobiochemistry, Faculty of Chemistry and Pharmaceutical Sciences, \\ Universidad de Chile, Independencia, Santiago, Chile.
}

"Department of Obstetrics and Gynecology, Center for Neuroscience and Regenerative Medicine, Uniformed Services University, Bethesda, MD, USA.

\section{Abstract}

Reproduction involves the integration of hormonal signals acting across multiple systems to generate a synchronised physiological output. A critical component of reproduction is the luteinising hormone $(\mathrm{LH})$ surge, which is mediated by oestradiol $\left(\mathrm{E}_{2}\right)$ and neuroprogesterone interacting to stimulate kisspeptin release in the rostral periventricular nucleus of the third ventricle in rats. Recent evidence indicates the involvement of both classical and membrane $\mathrm{E}_{2}$ and progesterone signalling in this pathway. A metabolite of gonadotrophin-releasing hormone (GnRH), GnRH-(1-5), has been shown to stimulate GnRH expression and secretion, and has a role in the regulation of lordosis. Additionally, gonadotrophin release-inhibitory hormone ( $\mathrm{GnIH})$ projects to and influences the activity of GnRH neurones in birds. Stress-induced changes in GnIH have been shown to alter breeding behaviour in birds, demonstrating another mechanism for the molecular control of reproduction. Peripherally, paracrine and autocrine actions within the gonad have been suggested as therapeutic targets for infertility in both males and females. Dysfunction of testicular prostaglandin synthesis is a possible cause of idiopathic male infertility. Indeed, local production of melatonin and corticotrophin-releasing hormone could influence spermatogenesis via immune pathways in the gonad. In females, vascular endothelial growth factor A has been implicated in an angiogenic process that mediates development of the corpus luteum and thus fertility via the Notch signalling pathway. Age-induced decreases in fertility involve ovarian kisspeptin and its regulation of ovarian sympathetic innervation. Finally, morphological changes in

Correspondence to: Lauren M. Rudolph, UCLA Department of Neurobiology, CHS 73-074, 650 Charles E. Young Dr. S., Los Angeles, CA 90095, USA (lrudolph@mednet.ucla.edu).

Disclaimer

The opinions or assertions contained herein are the private ones of the authors and are not to be construed as official or reflecting the views of the Department of Defense or the Uniformed Services University of the Health Sciences. 
the arcuate nucleus of the hypothalamus influence female sexual receptivity in rats. The processes mediating these morphological changes have been shown to involve the rapid effects of $E_{2}$ controlling synaptogenesis in this hypothalamic nucleus. In summary, this review highlights new research in these areas, focusing on recent findings concerning the molecular mechanisms involved in the central and peripheral hormonal control of reproduction.

\section{Keywords}

progesterone; oestrogens; androgens; paracrine; autocrine

\section{Introduction}

Reproduction is tightly regulated by the actions of hormones, both central and peripheral in origin. The 'classical' mechanisms of steroidal control of reproduction have been studied for decades, yet questions remain about how these hormones interact within the nervous system to elicit a coordinated response leading to ovulation and fertilisation. The common final pathway to the regulation of reproductive function is dependent on the appropriate functioning of the hypothalamic-pituitary-gonadal (HPG) axis. The proper coordination of the HPG axis relies largely on the inputs that regulate gonadotrophin-releasing hormone $(\mathrm{GnRH})$ release from hypothalamic neurones. In recent years, numerous nonclassical mechanisms have been uncovered, including newly understood membrane, autocrine and paracrine actions of steroid hormones. In addition, novel neuropeptides have been added to the list of neuroendocrine mediators such as the truncated GnRH [GnRH-(1-5)], as well as the inhibitory gonadotrophin release-inhibitory hormone $(\mathrm{GnIH})$. Together, these recently appreciated events have changed our understanding of the interaction of the HPG axis and the relationship between the periphery and the central nervous system in the regulation of reproduction.

\section{Control of the LH surge}

\section{Central nervous system (CNS) regulation of the LH surge}

As reviewed previously, oestradiol membrane signalling, comprising oestradiol $\left(\mathrm{E}_{2}\right)$ signalling that is initiated at the cell membrane, plays an important role in the CNS synthesis of progesterone (neuroP) needed for oestrogen positive-feedback of the LH surge (1). Although the preovulatory rise in circulating $\mathrm{E}_{2}$ is essential for stimulating gonadotrophin release (2-4), progesterone is also necessary for the LH surge (5-9). In ovariectomised rats and mice, $\mathrm{E}_{2}$ induces an LH release (10) and LH levels are augmented by additional application of progesterone $(11,12)$. Blocking progesterone receptor $(\mathrm{PR})$ or progesterone synthesis prevents the $\mathrm{E}_{2}$-induced $\mathrm{GnRH}$ and $\mathrm{LH}$ surges in ovariectomised rats $(5,13)$ and arrests the oestrous cycle in intact female rats (14). Most critically for this discussion, ablation of PR in kisspeptin (KP)-expressing neurones abrogates oestrogen positivefeedback (15), indicating that that both $\mathrm{E}_{2}$ and progesterone are necessary for surge release of $\mathrm{LH}$. 
Where does neuroP act to influence the LH surge? It is well established that GnRH neurones themselves do not express the requisite steroid hormone receptors, oestrogen receptor (ER)a and PR $(16,17)$. There is now solid evidence that the LH surge 'pattern generator', which integrates steroid hormone information and regulates oestrogen positive-feedback is a population of KP-expressing neurones of the rostral periventricular nucleus of the third ventricle (RP3V), an area that includes the anterior periventricular nucleus and the anteroventral periventricular nucleus (18-25). Kiss1 neurones in the RP3V are critical for GnRH secretion because KP released from Kiss1 neurones activates GnRH neurones via GPR54, a G-protein coupled receptor that binds KP (26-28). Although much of the work on steroid regulation of KP and its gene, Kiss 1, has focused on $\mathrm{E}_{2}(29,30)$, it is now evident that $E_{2}$ and neuroP function together to regulate KP. First, both ERa and PR are needed for positive-feedback of the LH surge $(31,32)$, and both have been localised in KP neurones, although neither are found in GnRH neurones $(20,33)$. Consistent with the need for $\mathrm{E}_{2}$ induced PRs for the LH surge, a substantial number of KP neurones in RP3V and the arcuate nucleus of the hypothalamus (ARH) express PR after $E_{2}$ treatment $(25,30,33,34)$. Coincident with this, rising $\mathrm{E}_{2}$ levels during pro-oestrus induce neuroP synthesis $(14,35)$.

A combination of in vitro and in vivo experiments have demonstrated that neuroP acts on KP neurones to mediate oestrogen positive-feedback (Fig. 1). Integrated steroid signalling was studied in a cell line (mHypoA51s) that approximates 'sexually mature' female hypothalamic neurones. These immortalised neurones have the characteristics of postpubertal RP3V KP neurones because they express ERa, PR and KP (36). As with KP neurones in vivo, $\mathrm{E}_{2}$ and the ERa agonist, PPT, induced KP and PR in mHypoA51s. Significantly, $\mathrm{E}_{2}$-induced PR up-regulation was dependent on an intracellular ER, whereas $\mathrm{KP}$ expression was stimulated by membrane-impermeable $\mathrm{E}_{2}\left(\mathrm{E}_{2}\right.$ coupled to bovine serum albumin; E-6-BSA). These data suggest that anterior hypothalamic KP neurones utilise both membrane-initiated and classical nuclear oestrogen signalling to up-regulate KP and PR, which are essential for the LH surge.

The nature of progesterone signalling in KP neurones remains to be clarified. In addition to classical nuclear PR, there are intriguing suggestions that KP neurones in vitro and in vivo have membrane progesterone receptors, especially $\mathrm{mPR} \beta$ (37). The mPRs are seventransmembrane proteins that activate $\mathrm{G}$ proteins that belong to the progestin and adipo $\mathrm{Q}$ receptor (PAQR) family not the classic G protein-coupled receptor (GPCR) family (38-40). PAQRs can signal through mitogen-activated protein kinase activation and increasing $\left[\mathrm{Ca}^{2+}\right]_{\mathrm{i}}$ (41-47); but see also (48). Studies in mHypoA51s indicate that classical PR is responsible for progesterone-induced signalling events. Treatment of $\mathrm{E}_{2}$-primed mHypoA51s with progesterone induces a rapid increase in free cytoplasmic calcium $\left(\left[\mathrm{Ca}^{2+}\right]_{\mathrm{i}}\right)$, which appears to be responsible for the release of KP induced by progesterone, whereas inhibition with RU486 prevents the $\left[\mathrm{Ca}^{2+}\right]_{\mathrm{i}}$ increase (36).

In vivo, preliminary experiments have demonstrated that exogenous progesterone rescued the LH surge in females whose hypothalamic steroidogenesis was blocked with the CYP11A1 inhibitor aminoglutethimide (AGT) (49). In AGT-treated animals, infusions of progesterone or KP into the diagonal band of Broca induced an LH surge, confirming that $\mathrm{KP}$ operates downstream of neuroP. Finally, KP knockdown in the RP3V prevented the $\mathrm{E}_{2}$ - 
induced LH surge (49). Most importantly, the ablation of PR in KP neurones in ovariectomised mice abrogates $E_{2}$ positive-feedback (15) demonstrating that that both $E_{2}$ and neuroP are necessary for the surge release of $\mathrm{LH}$.

\section{Molecular mechanisms of GnRH-(1-5) action}

The decapeptide GnRH (pGlu-His-Trp-Ser-Tyr-Gly-Leu-Arg-Pro-Gly-NH2) is highly conserved across species, suggesting its functional importance throughout evolution (50). GnRH is primarily known for its role in regulating reproductive function and behaviour via interaction with KP and its cognate receptor, GPR54, in the hypothalamus (51-57). Within each oestrous cycle, a rapid increase in GnRH secretion culminates in an LH surge, which precedes the onset of sexual receptivity and ovulation. In addition to its effects on the secretion of LH, GnRH can autoregulate its own biosynthesis and secretion via an ultrashortloop feedback mechanism (58-62).

GnRH not only functions in its full form, but also can signal via its metabolite, GnRH-(1-5). GnRH-(1-5) is produced by the cleavage of GnRH by the zinc metalloendopeptidase EC3.4.24.15 (EP24.15) at the covalent bond linking the fifth and sixth amino acids (63-65) (Fig. 2). Localisation of EP24.15 supports the involvement of EP24.15 in the modulation of hypothalamic GnRH neuronal function $(63,66)$. EP24.15 immunoreactivity is sensitive to hormonal fluctuations: increasing on pro-oestrous day of the rat oestrous cycle within the median eminence, with a peak expression coinciding with the LH surge (63). Unlike GnRH, GnRH-(1-5) robustly stimulates GnRH gene expression (67) and stimulates GnRH secretion (68). Moreover, the GnRH facilitation of lordosis behaviour is actually mediated by its metabolism to GnRH-(1-5) (69).

Interestingly, studies show that GnRH-(1-5) does not bind to the GnRH receptor (51) but binds to two orphan GPCRs: GPR101 (70) and GPR173 (71,72) (Fig. 2). Both GPR101 and GPR173 are members of the Rhodopsin class of receptors. The Rhodopsin family is the largest of the five groups of orphan receptors with 672 members of which 63 have no known ligands. Both GnRH-(1-5)-binding GPCRs are highly conserved and are highly expressed in the hypothalamus (Allen Brain Bank) $(73,74)$. In several species, the coding sequence for GPR101 is located on the X chromosome in a band that is syntenic between species (75). In mouse, GPR101 mRNA is 2186 bases, encoding a seven-transmembrane receptor that is approximately $51 \mathrm{kDa}$ (76). The sequenced GPR173 mRNA is 1122 bases, which translates to a 42-kDa seven-transmembrane receptor (73). Functional studies suggest that GnRH-(1-5) retards the cellular migration of neural cells via GPR173 (71-73). By contrast, GnRH-(1-5) may stimulate cellular migration and invasion of the extracellular matrix in endometrial cells via GPR101 (70,77).

These studies support the idea that GnRH-(1-5) represents another layer of regulatory complexity in tissues where $\mathrm{GnRH}$ is also produced. The identification of an endogenous ligand to an orphan GPCR is important because these receptors may have therapeutic potential (74). Furthermore, the identification of a GPCR that binds GnRH-(1-5) may help resolve some of the current quandaries regarding the actions of GnRH (agonist/antagonist) and enhance our understanding in the evolution of peptide metabolism and processing. 


\section{Role of GnIH in avian reproductive system; regulation of GnIH by photoperiod and stress and the effects of these changes on reproductive behaviours}

Although GnRH and its metabolite, GnRH-(1-5), are known for promoting reproductionrelated functions in the HPG axis, a more recently discovered hormone has been implicated as a potential brake on the HPG system. GnIH has received attention because of its role in the inhibition of activity of components of the HPG axis, including a reduction of sexual behaviour (78-86). Despite a great deal of investigation into its specific functions and the factors that regulate $\mathrm{GnIH}$, the full range of actions of $\mathrm{GnIH}$ within the central nervous system remain unknown. At present, we know that, in birds, $\mathrm{GnIH}$ projects to $\mathrm{GnIH}$ receptor-expressing GnRH-I and -II neurones in addition to the median eminence $(84,87)$. In several species of mammals, GnIH projects to and also influences the activity of GnRH neurones $(85,88)$, as well as the external layer of the median eminence (88-92), although this latter finding remains disputed $(85,93)$. There are $\mathrm{GnIH}$ projections to multiple other brain areas (e.g. brainstem) and possibly to the spinal cord $(84,93)$, although the function of $\mathrm{GnIH}$ in these extra-hypothalamic areas remains obscure. The GnIH content of the brain is influenced by changes in day length and the associated changing melatonin signal in seasonal breeders $(84,94-99)$. In birds, despite the influence of GnIH on GnRH neurones, it appears that $\mathrm{GnIH}$ does not influence the termination of reproduction at the end of the breeding season. Rather, it is more likely that GnIH plays a role in temporary reproductive suppression within the breeding season in response to different physiological stimuli, such as stress $(84,100-102)$.

The action of $\mathrm{GnIH}$ is not restricted to the brain and the anterior pituitary gland. GnIH and its receptor (GPR147) are synthesised in the gonads of both sexes of all vertebrates studied to date (103-108). Furthermore, in birds, GnIH-producing neurones in the brain project to the pars nervosa, suggesting that GnIH is released directly into the bloodstream (G. Bentley, unpublished observations). If confirmed, then not only can locally produced $\mathrm{GnIH}$ act within the gonads, but also neurally produced GnIH could be released to the general circulation and act upon peripheral targets.

It is possible that $\mathrm{GnIH-producing} \mathrm{neurones} \mathrm{can} \mathrm{be} \mathrm{subdivided} \mathrm{into} \mathrm{heterogenous}$ subpopulations that respond to unique environmental and physiological cues. For example, GnIH neurones express melatonin receptor (MelR) and glucocorticoid receptor (GR) mRNA. However, not all of the GnIH neurones express MelR or GR $(98,109)$ and it is not known whether single GnIH neurones can express both MelR and GR, suggesting that there could be MelR- and GR-specific subpopulations of GnIH neurones, each with potentially distinct functions. Thus, it remains to be determined whether or how melatonin and glucocorticoids interact to influence GnIH action within the brain.

In birds and mammals, melatonin and corticosterone can act on the gonadal GnIH system. This suggests the possibility that the neural and gonadal GnIH systems could differentially respond to hormones and, together, could coordinate a response to circulating hormones (perhaps via direct innervation of the gonad). Unfortunately, only in vitro preparations can be used to answer this question. Without separating the gonads from the blood circulation and from potential neural input, it is impossible to determine gonadal responses to a changing hormonal environment, especially if GnIH is present in circulating blood. 
However, in vivo studies in this area could also be very informative, especially if localised blockade of GnIH receptor could be induced in the gonads.

GnIH responses to chronic stress have been documented in male and female rats, with a significant impact on reproduction (109-111). To date, there has been only one study on chronic stress effects upon GnIH in birds with sex-specific effects of treatment. Female European starlings (Sturnus vulgaris) exhibited increased ovarian GnIH expression compared to their nonstressed counterparts and were also reported not to ovulate, whereas nonstressed animals did (111). Acute stressors can certainly influence the avian $\mathrm{GnIH}$ system, although these effects appear to depend on the species, the time of year, the sex of the bird and the stressor (112-114). In addition, some stressors influence the gonads directly rather than via neural GnIH (112). The same is true for chronic housing stress in European starlings, as noted above (111). Thus, it is clear that neural and GnIH systems can respond differently to any particular stressor, regardless of whether it is acute or chronic. Further studies in this area should determine the response of gonadal and neural $\mathrm{GnIH}$ systems to stressors and hormones, and should also assess communication between these GnIH systems in a variety of species.

\section{Local regulation of gonadal function}

\section{Autocrine and paracrine regulation of testicular function: molecular pathways involved in testis pathophysiology leading to infertility}

Gonadotrophins are key regulators of male gonadal function. LH and follicle-stimulating hormone (FSH) released from the pituitary reach the testis and exert their effects through receptors located in the plasma membrane of Leydig and Sertoli cells, respectively $(115,116)$. In addition, local factors and hormones influence testicular function via paracrine and autocrine mechanisms. Several molecules that reach the testis and/or are locally produced in the gonad regulate the activity of different cell types (e.g. Leydig cells, Sertoli cells, mast cells, macrophages, myofibroblasts), include peptides (117), neurotransmitters (118), neurohormones (119), cytokines (120) and prostaglandins (PGs) (121).

In this context, the neurohormones serotonin (122), melatonin (123) and corticotrophinreleasing hormone (CRH) (124) act in the testes as important negative regulators of cAMP and androgen production. Serotonin, melatonin and CRH can be produced within the CNS and secreted into peripheral circulation, or locally synthesised in the testes $(125,126)$. Melatonin and also serotonin inhibit steroidogenesis via their 5-HT 2 receptor- and Mel1a receptor-mediated signalling pathways, which influence CRH centrally $(125,127)$ and in the testes $(127,128)$. This CRH-mediated inhibition of steroid production occurs through the activation of tyrosine phosphatases, which reduces the phosphorylation of extracellular regulated kinase (ERK) and c-Jun N-terminal kinase, and subsequently down-regulates cjun, c-fos and steroid acute regulatory protein (StAR), thereby inhibiting testosterone production (128).

Melatonin has been postulated to have a physiological role as a paracrine signalling molecule, directly regulating the production of factors (e.g. immune, interleukin-2) in its immediate vicinity (129). Recent observations show that melatonin modulates local cellular 
activity in testicular immune cells, inducing the expression of antioxidant enzymes and reducing the generation of reactive oxygen species in mast cells. In testicular macrophages, melatonin inhibits cell proliferation, the expression of proinflammatory cytokines, interleukin- $1 \beta$ and tumour necrosis factor $\alpha$, and PG production (130). PGs are derived from arachidonic acid by the action of inducible isoenzyme cyclooxygenase (COX). In testicular biopsies of men with impaired spermatogenesis, COX-2 is expressed in immune cells, highlighting their relevance in testicular inflammation associated with idiopathic infertility (131). Furthermore, Leydig and Sertoli cells also produce PGs and express several prostanoid receptors $(132,133)$, suggesting autocrine/paracrine action in testicular somatic cells.

PGD2 has a stimulatory effect on basal testosterone production in Leydig cells (134), whereas PGF2 $\alpha$ exerts an inhibitory role in the expression of the StAR and $17 \beta-$ hydroxysteroid dehydrogenase (HSD), as well as in the synthesis of testosterone induced by human chorionic gonadotrophin (hCG)/LH (133), demonstrating that the role of PGs on steroidogenesis, spermatogenesis and ultimately fertility depends on the specific PG in question.

Recent research indicates that multiple local signals influence testicular physiology and are involved in the pathogenesis or maintenance of human infertility. Notably, male infertility results from endocrine dysfunctions associated with the hypothalamic-pituitary-testicular axis only in a small number of cases (135), suggesting the source of infertility likely occurs within local, intra-testicular pathways. Thus, new insights about how cell-cell interactions within the testes affect testicular function and fertility will contribute to the understanding of male reproductive physiopathology, and future studies focusing on testicular paracrine and autocrine interactions may lead to new therapeutic approaches to idiopathic male infertility.

\section{Follicular development, corpus luteum and progesterone regulation of ovarian vascularisation and molecular pathways involved}

Similar to testicular functions including spermatogenesis and steroidogenesis, ovarian follicular development and regression is a continuous and cyclic process that depends on a number of endocrine, paracrine and autocrine signals. In healthy tissues, physiological angiogenesis is mainly limited to the reproductive system. The ovarian vasculature is closely associated with preovulatory follicle and corpus luteum during the ovarian cycle and is one of the few sites where nonpathological development and regression of blood vessels occurs in the adult. Recently, local factors such as vascular endothelial growth factor A (VEGF-A) and angiopoietins, which act specifically on vascular endothelial cells or pericytes and smooth muscle to control angiogenesis or angiolysis, were identified in the growing follicle and corpus luteum of several species, including humans (136).

VEGF-A is a key angiogenic factor involved in the formation of new blood vessels within many tissues. It is required to initiate the formation of new immature vessels by promoting endothelial cell proliferation and vascular permeability. Inhibition of VEGF-A and angiopoietin 1 (ANGPT1) action in rat ovaries by intrabursal administration of VEGF-ATrap or ANGPT1 antibodies, respectively, produces an imbalance in the ratio of antiapoptotic : pro-apoptotic proteins leading to greater follicular atresia $(137,138)$. In addition, 
VEGF-A prevents apoptosis and stimulates the proliferation of granulosa and theca cells of antral follicles through a direct interaction with its KDR receptor localised in granulosa cells, a pathway that involves phosphoinositide 3-kinase (PI3K)/AKT (139). Furthermore, in vitro studies performed in early antral follicles and granulosa cell cultures isolated from rat demonstrate that VEGF acts directly on follicular cells synergistically with FSH and $\mathrm{E}_{2}$, preventing apoptosis and stimulating proliferation, thus promoting follicular development and the selection of the follicle to ovulate (140). Such work reported a direct role for VEGF in early antral follicles mediated by the PI3K/AKT and ERK1/2 pathways, besides the classical and well known proangiogenic function. Together, these data support the notion that angiogenic factors have an important role in controlling ovarian function.

In vitro studies have shown that Notch signalling is critical for the survival of luteal cells isolated from pregnant rats (141). Local Notch inhibition decreases progesterone levels and cell survival, confirming that Notch has a direct action on both steroidogenesis and luteal viability (141). The Notch signalling pathway is a cell-cell communication pathway that is evolutionarily conserved from Drosophila to humans. To date, four different Notch receptors (Notch 1, 2, 3 and 4) and five different ligands (Jagged-1 and -2 and DLL-1 -3 and -4) have been identified in mammals. This Notch system regulates cell fate, proliferation and death. The Notch genes encode transmembrane receptors, which, upon binding their ligand, are cleaved, releasing the intracellular domain. The intracellular portion of the receptor translocates to the nucleus to act as a transcriptional coactivator, regulating cell fate genes (142).

Moreover, in the rat, there is an interaction between the Notch signalling pathway and progesterone that maintains the functionality of the corpus luteum (143). Notch signalling augments P450scc synthesis, leading to an increased synthesis of progesterone, which in turn regulates the activated intracellular Notch domain. Thus, Notch induces progesterone production in vitro through the activation of cytochrome $\mathrm{P} 450$ cholesterol side chain cleavage enzyme (P450scc) and decreases apoptosis-mediated cell death. This is the first evidence that there is cross-talk between the Notch signalling system and progesterone, which increases the survival of luteal cells. Also, the Notch/PI3K/AKT signalling pathway might be interacting with progesterone, intensifying the survival role of this hormone in luteal cells. Nevertheless, future studies are required to thoroughly investigate this newly discovered Notch-progesterone relationship and how it contributes to ovarian function and reproduction as a whole.

\section{Ovarian kisspeptin and its role in follicular development}

Reproduction in females requires an LH surge, which is centrally regulated by KP. However, $\mathrm{KP}$ is found in many peripheral organs $(144,145)$, in particular, the ovary, which expresses $\mathrm{KP}$ and its receptor, GPR54, suggesting a role for KP in the peripheral control of reproductive events. KP expression in the ovary fluctuates throughout the oestrous cycle, strongly suggesting that it may be involved locally in the ovulatory cycle and luteinisation (146-148); but see also (28). However, the mechanisms of action of KP in the ovary, such as paracrine or autocrine functions remain largely unknown. 
A recent study demonstrated that intraovarian administration of a KP antagonist (p234) delays vaginal opening and alters the oestrous cycle in rats (147). Additionally, local administration of exogenous KP decreases antral follicle and corpora lutea number in fertile and subfertile rats, which was reversed by p234 treatment, suggesting that KP also participates in both follicular development and ovulation at the level of the ovary (149). Moreover, during ovulation in humans and nonhuman primates, ovarian KP and GPR54 mRNA increases with other ovulation-associated genes, such as COX-2 and progesterone receptor. The ovarian administration of the COX-2 inhibitor, indomethacin, disrupted the ovulatory process in rats, supporting the idea of a local role of KP and GRP54 in ovulation (150). It appears that KP regulates progesterone secretion from luteal cells as well. In isolated chicken granulosa cells, KP stimulates progesterone secretion, possibly by directly altering levels of steroidogenic enzymes, including StAR, P450scc, which converts cholesterol to pregnenolone, and $3 \beta$-HSD (151), which converts pregnenolone to progesterone. Similarly, in rat luteal cells, KP increased progesterone production via ERK1/2 signalling and increased the expression of StAR and CYP11A mRNA (152). Furthermore, administration of a GPR54 antagonist, p234, inhibited progesterone secretion in granulosa cell cultures treated with hCG, implicating KP in the luteinisation of granulosa cells (148). Together, these data suggest a potential role of KP in the local control of ovarian function, potentially via progesterone synthesis. These and future studies involving paracrine and autocrine actions of ovarian KP will clarify the molecular mechanisms involved in the regulation of follicular development and ovulation during reproductive life and ovarian ageing.

Although a decreased follicular pool indicates physiological ageing of the ovary (153), an increased rate of follicular loss is also a pathology that affects the follicular reserve pool, and thereby fertility, in humans and other mammals (154). Reproductive ageing in women begins with shortened menstrual cycles, smaller increases in FSH and decreased levels of inhibin (155), which results in accelerated follicular growth and premature exhaustion of the follicular pool. One of the mechanisms involved in ovarian ageing is increased sympathetic nerve activity. Ovaries of postmenopausal women ( 251 years old) have a higher density of innervation compared to age-matched controls $(156,157)$. In the rat, reproductive ageing is associated with increased ovarian sympathetic activity, which is strongly correlated with the spontaneous appearance of follicular cysts and a loss of preantral follicles $(158,159)$. Indeed, the highest sympathetic innervation is found in postmenopausal women, suggesting a correlation between ageing-induced infertility and sympathetic nerve activation. Recent findings indicate that sympathetic innervation may be controlling age-induced infertility via regulation of KP because ovarian sympathectomy diminishes KP levels (A. Paredes, unpublished observations). Additionally, during reproductive ageing, KP expression in the ovary increases from the subfertile to infertile period and is directly correlated with the increase in ovarian norepinephrine observed with ageing $(149,158)$, suggesting that KP may be directly controlled by sympathetic innervation of the ovary (147), as well as supporting the idea that KP is regulated by the adrenergic system and that both the adrenergic system and KP participate in the local regulation of follicle development and ovulation during reproductive ageing. Furthermore, KP is involved in follicular dynamics: intraovarian administration of KP produced an increase in the numbers of corpora lutea and type III 
follicles in fertile and subfertile periods, which was reversed by KP receptor antagonism. Future studies should address the potential autocrine and paracrine roles of KP in the ovary, specifically the interaction of KP, steroidogenic pathways and sympathetic innervation and how they relate to reproductive outcomes across the lifespan.

\section{Morphological changes in ARH initiated by oestradiol membrane signalling that mediate lordosis behaviour}

Another key component to reproduction in rodents is female sexual receptivity, which is mediated by $\mathrm{E}_{2}$-dependent alterations in hypothalamic neuronal structure. Although the molecular bases of $\mathrm{E}_{2}$-dependent facilitation of female sexual receptivity have more recently been described in detail, the understanding that steroid hormones exert behavioural effects via changes in neural morphology is a well established phenomenon. The most well known example of $\mathrm{E}_{2}$-induced changes in dendritic structure regulating memory-related behaviour is from the hippocampus (160), whereas $\mathrm{E}_{2}$-induced changes in dendrites in the hypothalamus have also been known for some time (161). Indeed, changes in dendritic morphology are critical for the lordosis-regulating circuit (162), which extends from the ARH to the medial preoptic nucleus (MPN), to the ventromedial nucleus of the hypothalamus (VMH). Recent studies have begun to clarify the molecular mechanisms by which morphological changes in the ARH-MPN-VMH circuit allow for expression of lordosis behaviour. The primary step of $\mathrm{E}_{2}$ signalling in the ARH occurs via ERa transactivation of mGluR1a, which initiates morphological changes that are coincident with and required for the display of lordosis behaviour. Within $4 \mathrm{~h}$ after $\mathrm{E}_{2}$ treatment, immature, filapodia-like dendritic spines are formed in the ARH (162). Twenty-four hours after $E_{2}$ treatment, there is a shift in the proportion of dendritic spines, with a decrease in filapodia and a concomitant increase in mature, mushroom-shaped spines (162). The formation of new spines is necessary for the $\mathrm{E}_{2}$-induced lordosis because blocking spine formation significantly reduces the expression of sexual receptivity (162).

Although it appears that spinogenesis is initiated by the action of $E_{2}$ at membrane ERa, it is unclear what molecular mechanisms underlie spine maturation. Evidence from other circuits suggests a role for the G-protein coupled ER, GPR30, in spine maturation and stabilisation. GPR30 is localised in spine heads, associates with PSD-95, and is regulated by $\mathrm{E}_{2}$ $(163,164)$. In the dorsal hippocampus, the GPR30 agonist, G1, increases PSD-95 immunoreactivity, suggesting a role for GPR30 in spine maturation (164). Indeed, this receptor has been implicated in the initiation of lordosis behaviour on the basis that the partial GPR30 agonist but ERa antagonist, ICI 182,780, facilitates lordosis in $\mathrm{E}_{2}$-primed nonreceptive rats (165). Other studies suggest there could be a role for the STX-activated $\mathrm{G}_{\mathrm{q}}$-coupled membrane ER in the ARH-MPN circuit mediating sexual receptivity. STX is a tamoxifen analogue that does not bind to classical ERa or GPR30 but is blocked by the ER antagonist ICI 182,780 and has pharmacological profile similar to those of the ERa-specific agonist, PPT (166-168). STX treatment induces $\mu$-opioid receptor (MOR) internalisation in the MPN and facilitates lordosis behaviour (169). Alternatively, spine maturation could be mediated by extra-neuronal mechanisms, such as astrocytic contact with neurones, which alters dendritic spine formation and stabilisation (170). 
Additionally, it is unclear whether $\mathrm{E}_{2}$ induces spinogenesis in the same population of neurones in the ARH that express ERa, the neuropeptide Y (NPY) neurones, which are the initial site of the action of $E_{2}$ in the ARH-MPN-VMH circuit, or whether $E_{2}$ is acting transsynaptically to induce spines on pro-opiomelanocortin (POMC) neurones, which release $\beta$-endorphin onto MORs in the MPN. Recent data suggest that the NPY neurones and not POMC neurones undergo spinogenesis, suggesting that spine formation occurs directly within the neurones where initial $E_{2}$ activation of ERa occurs (171). Regardless of the site of spinogenesis within the ARH, it is clear that spine maturation in this nucleus is coincident with lordosis behaviour, and also that blocking spinogenesis here reduces female sexual receptivity. To a first approximation, the timeline from $\mathrm{E}_{2}$ treatment to the presence of mature dendritic spines is known. However, the time when fully functional synapses appear remains to be determined. Within $1 \mathrm{~h}$ of $\mathrm{E}_{2}$ treatment, cofilin is deactivated via phosphorylation, which permits spinogenesis (162), and, in the MPN, MOR is activated/ internalised, indicating that the ARH to MPN part of the circuit is functional (172). At $4 \mathrm{~h}$ post- $\mathrm{E}_{2}$ treatment, filapodial spines are present, although these thin, labile spines are not considered to mediate functional synapses (173). At $20 \mathrm{~h}$ after $\mathrm{E}_{2}$ treatment, the first time point when lordosis behaviour can be elicited with supplemental hormone treatment, there is an increase in the proportion of mushroom spines that are generally assumed to be indicative of functional synapses (162) and that contain the machinery required for synaptic transmission (e.g. PSD-95). Future studies should address the time course of this $\mathrm{E}_{2}$ dependent spine maturation and the potential involvement of non-traditional ER in this process.

\section{Conclusions}

Taken together, these recent findings highlight both the redundancy and complexity of the hormonal control of reproduction: what was once considered to be a simple, direct circuit with a handful of steroid hormones and cognate receptors is continually updated with novel hormone regulators and mechanisms of hormone synthesis and action. However, the classical aspects of gonadal hormone control of reproduction remain intact, demonstrating that there are multiple levels of control of the HPG axis, both centrally and peripherally. Future studies will likely only add to this increasingly complex circuit that regulates reproduction.

\section{References}

1. Kuo J, Micevych P. Neurosteroids, trigger of the LH surge. J Steroid Biochem Mol Biol. 2012; 131:57-65. [PubMed: 22326732]

2. Brom GM, Schwartz NB. Acute changes in the estrous cycle following ovariectomy in the golden hamster. Neuroendocrinology. 1968; 3:366-377. [PubMed: 5752038]

3. Ferin M, Tempone A, Zimmering PE, Van de Wiele RL. Effect of antibodies to 17beta-estradiol and progesterone on the estrous cycle of the rat. Endocrinology. 1969; 85:1070-1078. [PubMed: 5388410]

4. Labhsetwar AP. Role of estrogens in ovulation: a study using the estrogen-antagonist, I.C.I. 46,474. Endocrinology. 1970; 87:542-551. [PubMed: 5463820]

5. Micevych P, Sinchak K, Mills RH, Tao L, LaPolt P, Lu JK. The luteinizing hormone surge is preceded by an estrogen-induced increase of hypothalamic progesterone in ovariectomized and adrenalectomized rats. Neuroendocrinology. 2003; 78:29-35. [PubMed: 12869797] 
6. Hibbert ML, Stouffer RL, Wolf DP, Zelinski-Wooten MB. Midcycle administration of a progesterone synthesis inhibitor prevents ovulation in primates. Proc Natl Acad Sci USA. 1996; 93:1897-1901. [PubMed: 8700855]

7. Remohi J, Balmaceda JP, Rojas FJ, Asch RH. The role of pre-ovulatory progesterone in the midcycle gonadotrophin surge, ovulation and subsequent luteal phase: studies with RU486 in rhesus monkeys. Hum Reprod. 1988; 3:431-435. [PubMed: 3134390]

8. DePaolo LV. Attenuation of preovulatory gonadotrophin surges by epostane: a new inhibitor of 3 beta-hydroxysteroid dehydrogenase. J Endocrinol. 1988; 118:59-68. [PubMed: 3137304]

9. Mahesh VB, Brann DW. Interaction between ovarian and adrenal steroids in the regulation of gonadotropin secretion. J Steroid Biochem Mol Biol. 1992; 41:495-513. [PubMed: 1562521]

10. DePaolo LV, Barraclough CA. Dose dependent effects of progesterone on the facilitation and inhibition of spontaneous gonadotropin surges in estrogen treated ovariectomized rats. Biol Reprod. 1979; 21:1015-1023. [PubMed: 393308]

11. Petersen SL, Keller ML, Carder SA, McCrone S. Differential effects of estrogen and progesterone on levels of POMC messenger RNA levels in the arcuate nucleus - relationship to the timing of LH surge release. J Neuroendocrinol. 1993; 5:643-648. [PubMed: 8680436]

12. Petersen SL, McCrone S, Keller M, Shores S. Effects of estrogen and progesterone on luteinizing hormone-releasing hormone messenger ribonucleic acid levels: consideration of temporal and neuroanatomical variables. Endocrinology. 1995; 136:3604-3610. [PubMed: 7628399]

13. Chappell PE, Levine JE. Stimulation of gonadotropin-releasing hormone surges by estrogen. I. Role of hypothalamic progesterone receptors. Endocrinology. 2000; 141:1477-1485. [PubMed: 10746653]

14. Micevych PE, Sinchak K. The neurosteroid progesterone underlies estrogen positive feedback of the LH surge. Front Endocrinol. 2011; 2:90.

15. Stephens SB, Tolson KP, Rouse MLJ, Poling MC, Hashimoto-Parktya M, Mellon PL, Kauffman AS. Absent progesterone signaling in kisspeptin neurons disrupts the LH surge and impairs fertility in female mice. Endocrinology. 2015; 156:3091-3097. [PubMed: 26076042]

16. Herbison AE, Theodosis DT. Localization of oestrogen receptors in preoptic neurons containing neurotensin but not tyrosine hydroxylase, cholecystokinin or luteinizing hormone-releasing hormone in the male and female rat. Neuroscience. 1992; 50:283-298. [PubMed: 1359459]

17. Shivers BD, Harlan RE, Morrell JI, Pfaff DW. Absence of oestradiol concentration in cell nuclei of LHRH-immunoreactive neurones. Nature. 1983; 304:345-347. [PubMed: 6348552]

18. Wintermantel TM, Campbell RE, Porteous R, Bock D, Grone HJ, Todman MG, Korach KS, Greiner E, Perez CA, Schutz G, Herbison AE. Definition of estrogen receptor pathway critical for estrogen positive feedback to gonadotropin-releasing hormone neurons and fertility. Neuron. 2006; 52:271-280. [PubMed: 17046690]

19. Han SK, Gottsch ML, Lee KJ, Popa SM, Smith JT, Jakawich SK, Clifton DK, Steiner RA, Herbison AE. Activation of gonadotropin-releasing hormone neurons by kisspeptin as a neuroendocrine switch for the onset of puberty. J Neurosci. 2005; 25:11349-11356. [PubMed: 16339030]

20. Smith JT, Cunningham MJ, Rissman EF, Clifton DK, Steiner RA. Regulation of Kiss1 gene expression in the brain of the female mouse. Endocrinology. 2005; 146:3686-3692. [PubMed: 15919741]

21. Liu X, Lee K, Herbison AE. Kisspeptin excites gonadotropin-releasing hormone neurons through a phospholipase C/calcium-dependent pathway regulating multiple ion channels. Endocrinology. 2008; 149:4605-4614. [PubMed: 18483150]

22. Dumalska I, Wu M, Morozova E, Liu R, van den Pol A, Alreja M. Excita-tory effects of the puberty-initiating peptide kisspeptin and group I metabotropic glutamate receptor agonists differentiate two distinct subpopulations of gonadotropin-releasing hormone neurons. J Neurosci. 2008; 28:8003-8013. [PubMed: 18685025]

23. Zhang C, Roepke TA, Kelly MJ, Ronnekleiv OK. Kisspeptin depolarizes gonadotropin-releasing hormone neurons through activation of TRPC-like cationic channels. J Neurosci. 2008; 28:44234434. [PubMed: 18434521] 
24. Pielecka-Fortuna J, Chu Z, Moenter SM. Kisspeptin acts directly and indirectly to increase gonadotropin-releasing hormone neuron activity and its effects are modulated by estradiol. Endocrinology. 2008; 149:1979-1986. [PubMed: 18162521]

25. Clarkson J, D'Anglemont de Tassigny X, Moreno AS, Colledge WH, Her-bison AE. KisspeptinGPR54 signaling is essential for preovulatory gonadotropin-releasing hormone neuron activation and the luteinizing hormone surge. J Neurosci. 2008; 28:8691-8697. [PubMed: 18753370]

26. Navarro VM, Castellano JM, Fernandez-Fernandez R, Barreiro ML, Roa J, Sanchez-Criado JE, Aguilar E, Dieguez C, Pinilla L, Tena-Sempere M. Developmental and hormonally regulated messenger ribonucleic acid expression of KiSS-1 and its putative receptor GPR54 in rat hypothalamus and potent LH releasing activity of KiSS-1 peptide. Endocrinology. 2004; 145:4565-4574. [PubMed: 15242985]

27. Seminara SB. Metastin and its G protein-coupled receptor, GPR54: critical pathway modulating GnRH secretion. Front Neuroendocrinol. 2005; 26:131-138. [PubMed: 16309735]

28. Kirilov M, Clarkson J, Liu X, Roa J, Campos P, Porteous R, Schutz G, Herbison AE. Dependence of fertility on kisspeptin-Gpr54 signaling at the GnRH neuron. Nat Commun. 2013; 4:2492. [PubMed: 24051579]

29. Kinoshita M, Tsukamura H, Adachi S, Matsui H, Uenoyama Y, Iwata K, Yamada S, Inoue K, Ohtaki T, Matsumoto H, Maeda K. Involvement of central metastin in the regulation of preovulatory luteinizing hormone surge and estrous cyclicity in female rats. Endocrinology. 2005; 146:4431-4436. [PubMed: 15976058]

30. Smith JT, Popa SM, Clifton DK, Hoffman GE, Steiner RA. Kiss1 neurons in the forebrain as central processors for generating the preovulatory luteinizing hormone surge. J Neurosci. 2006; 26:6687-6694. [PubMed: 16793876]

31. Chappell PE, Lee J, Levine JE. Stimulation of gonadotropin-releasing hormone surges by estrogen. II. Role of cyclic adenosine $3^{\prime} 5^{\prime}$-monophosphate. Endocrinology. 2000; 141:1486-1492. [PubMed: 10746654]

32. Chappell PE, Schneider JS, Kim P, Xu M, Lydon JP, O’Malley BW, Levine JE. Absence of gonadotropin surges and gonadotropin-releasing hormone self- priming in ovariectomized (OVX), estrogen (E2)-treated, progesterone receptor knockout (PRKO) mice. Endocrinology. 1999; 140:3653-3658. [PubMed: 10433223]

33. Zhang J, Yang L, Lin N, Pan X, Zhu Y, Chen X. Aging-related changes in RP3V kisspeptin neurons predate the reduced activation of GnRH neurons during the early reproductive decline in female mice. Neurobiol Aging. 2014; 35:655-668. [PubMed: 24112790]

34. Smith JT, Clay CM, Caraty A, Clarke IJ. KiSS-1 messenger ribonucleic acid expression in the hypothalamus of the ewe is regulated by sex steroids and season. Endocrinology. 2007; 148:11501157. [PubMed: 17185374]

35. Soma KK, Sinchak K, Lakhter A, Schlinger BA, Micevych PE. Neurosteroids and female reproduction: estrogen increases 3beta-HSD mRNA and activity in rat hypothalamus. Endocrinology. 2005; 146:4386-4390. [PubMed: 16020475]

36. Mittelman-Smith MA, Wong AM, Kathiresan AS, Micevych PE. Classical and membrane-initiated estrogen signaling in an in vitro model of anterior hypothalamic kisspeptin neurons. Endocrinology. 2015; 156:2162-2173. [PubMed: 25730107]

37. Zuloaga DG, Yahn SL, Pang Y, Quihuis AM, Oyola MG, Reyna A, Thomas P, Handa RJ, Mani SK. Distribution and estrogen regulation of membrane progesterone receptor-beta in the female rat brain. Endocrinology. 2012; 153:4432-4443. [PubMed: 22778216]

38. Thomas P, Pang Y, Dong J, Groenen P, Kelder J, de Vlieg J, Zhu Y, Tubbs C. Steroid and G protein binding characteristics of the seatrout and human progestin membrane receptor alpha subtypes and their evolutionary origins. Endocrinology. 2007; 148:705-718. [PubMed: 17082257]

39. Tang YT, Hu T, Arterburn M, Boyle B, Bright JM, Emtage PC, Funk WD. PAQR proteins: a novel membrane receptor family defined by an ancient 7-transmembrane pass motif. J Mol Evol. 2005; 61:372-380. [PubMed: 16044242]

40. Moussatche P, Lyons TJ. Non-genomic progesterone signalling and its non-canonical receptor. Biochem Soc Trans. 2012; 40:200-204. [PubMed: 22260690] 
41. Thomas P, Pang Y. Membrane progesterone receptors: evidence for neuroprotective, neurosteroid signaling and neuroendocrine functions in neuronal cells. Neuroendocrinology. 2012; 96:162-171. [PubMed: 22687885]

42. Pang Y, Dong J, Thomas P. Characterization, neurosteroid binding and brain distribution of human membrane progesterone receptors delta and epsilon (mPRdelta and MPR \{epsilon\}) and mPRdelta involvement in neurosteroid inhibition of apoptosis. Endocrinology. 2013; 154:283-295. [PubMed: 23161870]

43. Yoshikuni M, Nagahama Y. Involvement of an inhibitory G-protein in the signal transduction pathway of maturation-inducing hormone (17 alpha,20 beta-dihydroxy-4-pregnen-3-one) action in rainbow trout (Oncorhynchus mykiss) oocytes. Dev Biol. 1994; 166:615-622. [PubMed: 7813780]

44. Karteris E, Zervou S, Pang Y, Dong J, Hillhouse EW, Randeva HS, Thomas P. Progesterone signaling in human myometrium through two novel membrane $\mathrm{G}$ protein-coupled receptors: potential role in functional progesterone withdrawal at term. Mol Endocrinol. 2006; 20:15191534. [PubMed: 16484338]

45. Bashour NM, Wray S. Progesterone directly and rapidly inhibits GnRH neuronal activity via progesterone receptor membrane component 1. Endocrinology. 2012; 153:4457-4469. [PubMed: 22822163]

46. Hanna R, Pang Y, Thomas P, Zhu Y. Cell-surface expression, progestin binding, and rapid nongenomic signaling of zebrafish membrane progestin receptors alpha and beta in transfected cells. J Endocrinol. 2006; 190:247-260. [PubMed: 16899559]

47. Ashley RL, Clay CM, Farmerie TA, Niswender GD, Nett TM. Cloning and characterization of an ovine intracellular seven transmembrane receptor for progesterone that mediates calcium mobilization. Endocrinology. 2006; 147:4151-4159. [PubMed: 16794007]

48. Krietsch T, Fernandes MS, Kero J, Losel R, Heyens M, Lam EW, Huhtaniemi I, Brosens JJ, Gellersen B. Human homologs of the putative G protein-coupled membrane progestin receptors (mPRalpha, beta, and gamma) localize to the endoplasmic reticulum and are not activated by progesterone. Mol Endocrinol. 2006; 20:3146-3164. [PubMed: 16959873]

49. Paaske, LK.; Chuon, T.; Micevych, P.; Sinchak, K. AVPV Kisspeptin Neurons Mediate Neuroprogesterone Induction of the Leuteinizing Hormone Surge. Society for Neuroscience; Washington, DC: 2014.

50. Gorbman A, Sower SA. Evolution of the role of GnRH in animal (Metazoan) biology. Gen Comp Endocrinol. 2003; 134:207-213. [PubMed: 14636626]

51. Ojeda SR, Lomniczi A. Puberty in 2013: unraveling the mystery of puberty. Nat Rev Endocrinol. 2014; 10:67-69. [PubMed: 24275741]

52. Semaan SJ, Tolson KP, Kauffman AS. The development of kisspeptin circuits in the Mammalian brain. Adv Exp Med Biol. 2013; 784:221-252. [PubMed: 23550009]

53. Yeo SH. Neuronal circuits in the hypothalamus controlling gonadotrophin-releasing hormone release: the neuroanatomical projections of kisspeptin neurons. Exp Physiol. 2013; 98:1544-1549. [PubMed: 23934040]

54. Kelly MJ, Zhang C, Qiu J, Ronnekleiv OK. Pacemaking kisspeptin neurons. Exp Physiol. 2013; 98:1535-1543. [PubMed: 23884368]

55. Okamura H, Tsukamura H, Ohkura S, Uenoyama Y, Wakabayashi Y, Maeda K. Kisspeptin and GnRH pulse generation. Adv Exp Med Biol. 2013; 784:297-323. [PubMed: 23550012]

56. Smith JT. Sex steroid regulation of kisspeptin circuits. Adv Exp Med Biol. 2013; 784:275-295. [PubMed: 23550011]

57. Terasawa E, Guerriero KA, Plant TM. Kisspeptin and puberty in mammals. Adv Exp Med Biol. 2013; 784:253-273. [PubMed: 23550010]

58. DePaolo LV, King RA, Carillo AJ. In vivo and in vitro examination of an autoregulatory mechanism for luteinizing hormone-releasing hormone. Endocrinology. 1987; 120:272-279. [PubMed: 3096701]

59. Sarkar DK. In vivo secretion of LHRH in ovariectomized rats is regulated by a possible autofeedback mechanism. Neuroendocrinology. 1987; 45:510-513. [PubMed: 3302744]

60. Sarkar DK, Chiappa SA, Fink G, Sherwood NM. Gonadotropin-releasing hormone surge in proestrous rats. Nature. 1976; 264:461-463. [PubMed: 794737] 
61. Roth C, Schricker M, Lakomek M, Strege AHI, Luft H, Munzel U, Wuttke W, Jarry H. Autoregulation of the gonadotropin-releasing hormone $(\mathrm{GnRH})$ system during puberty: effects of antagonistic versus agonistic GnRH analogs in a female rat model. J Endocrinol. 2001; 169:361371. [PubMed: 11312152]

62. Zanisi M, Messi EM, Motta M, Martini L. Ultrashort feedback control of luteinizing hormonereleasing hormone neuronal system. Endocrinology. 1987; 121:2199-2204. [PubMed: 3315636]

63. Wu TJ, Pierotti AR, Jakubowski M, Sheward WJ, Glucksman MJ, Smith AI, King JC, Fink G, Roberts JL. Endopeptidase EC 3.4.24.15 presence in the rat median eminence and hypophysial portal blood and its modulation of the luteinizing hormone surge. J Neuroendocrinol. 1997; 9:813822. [PubMed: 9419832]

64. Shrimpton CN, Glucksman MJ, Lew RA, Tullai JW, Margulies EH, Roberts JL, Smith AI. Thiol activation of endopeptidase EC 3.4.24.15. A novel mechanism for the regulation of catalytic activity. J Biol Chem. 1997; 272:17393-17399.

65. Smith AI, Tetaz T, Roberts JL, Glucksman MJ, Clarke IJ, Lew RA. The role of EC 3.4.24.15 in the post-secretory regulation of peptide signals. Biochimie. 1994; 76:288-294. [PubMed: 7819337]

66. Roberts JL, Mani SK, Woller MJ, Glucksman MJ, Wu TJ. LHRH-(1-5): a bioactive peptide regulating reproduction. Trends Endocrinol Metab. 2007; 18:386-392. [PubMed: 17997103]

67. Wu TJ, Mani SK, Glucksman MJ, Roberts JL. Stimulation of luteinizing hormone-releasing hormone (LHRH) gene expression in GT1-7 cells by its metabolite, LHRH-(1-5). Endocrinology. 2005; 146:280-286. [PubMed: 15486221]

68. Larco DO, Williams M, Schmidt L, Sabel N, Woller MJ, Wu TJ. Autoshortloop feedback regulation of pulsatile gonadotropin-releasing hormone $(\mathrm{GnRH})$ secretion by its metabolite, GnRH-(1-5). Endocr J. 2015; 49:470-478.

69. Wu TJ, Glucksman MJ, Roberts JL, Mani SK. Facilitation of lordosis in rats by a metabolite of luteinizing hormone releasing hormone (LHRH). Endocrinology. 2006; 147:2544-2549. [PubMed: 16497796]

70. Cho-Clark MC, Larco DO, Semsarzadeh N, Vasta FC, Mani SK, Wu TJ. GnRH-(1-5) transactivates EGFR in Ishikawa human endometrial cells via an orphan $\mathrm{G}$ protein-coupled receptor. Mol Endocrinol. 2014; 28:80-98. [PubMed: 24264576]

71. Larco DO, Cho-Clark M, Mani SK, Wu TJ. The metabolite GnRH-(1-5) inhibits the migration of immortalized GnRH neurons. Endocrinology. 2013; 154:783-795. [PubMed: 23321696]

72. Larco DO, Semsarzadeh N, Cho-Clark M, Mani SK, Wu TJ. $\beta$-Arrestin 2 is a mediator of GnRH(1-5) signaling in immortalized GnRH neurons. Endocrinology. 2013; 154:4726-4736. [PubMed: 24140715]

73. Larco DO, Cho-Clark M, Semsarzadeh N, Mani SK, Wu TJ. The novel actions of the metabolite GnRH-(1-5) are mediated by a G protein-coupled receptor. Front Endocrinol. 2013; 4:83.

74. Regard JB, Sato IT, Coughlin SR. Anatomical profiling of G protein-coupled receptor expression. Cell. 2008; 135:561-571. [PubMed: 18984166]

75. Lee DK, George SR, Cheng R, Nguyen T, Liu Y, Brown M, Lynch KR, O’Dowd BF. Identification of four novel $G$ protein-coupled receptors expressed in the brain. Brain Res Mol Brain Res. 2001; 86:13-22. [PubMed: 11165367]

76. Bates B, Zhang L, Nawoschik S, Kodangattil S, Tseng E, Kopsco D, Kramer A, Shan Q, Taylor N, Johnson J, Sun Y, Chen HM, Blatcher M, Paulsen JE, Pausch MH. Characterization of Gpr101 expression and G-protein coupling selectivity. Brain Res. 2006; 1087:1-14. [PubMed: 16647048]

77. Cho-Clark M, Larco DO, Zahn BR, Mani SK, Wu TJ. GnRH-(1-5) activates matrix metallopeptidase-9 to release epidermal growth factor and promote cellular invasion. Mol Cell Endocrinol. 2015; 415:114-125. [PubMed: 26277400]

78. Clarke IJ, Sari IP, Qi Y, Smith JT, Parkington HC, Ubuka T, Iqbal J, Li Q, Tilbrook A, Morgan K, Pawson AJ, Tsutsui K, Millar RP, Bentley GE. Potent action of RFamide-related peptide-3 on pituitary gonadotropes indicative of a hypophysiotropic role in the negative regulation of gonadotropin secretion. Endocrinology. 2008; 149:5811-5821. [PubMed: 18617613]

79. Bentley GE, Jensen JP, Kaur GJ, Wacker DW, Tsutsui K, Wingfield JC. Rapid inhibition of female sexual behavior by gonadotropin-inhibitory hormone (GnIH). Horm Behav. 2006; 49:550-555. [PubMed: 16460739] 
80. Tsutsui K, Saigoh E, Ukena K, Teranishi H, Fujisawa Y, Kikuchi M, Ishii S, Sharp PJ. A novel avian hypothalamic peptide inhibiting gonadotropin release. Biochem Biophys Res Commun. 2000; 275:661-667. [PubMed: 10964719]

81. Ubuka T, Ukena K, Sharp PJ, Bentley GE, Tsutsui K. Gonadotropin-inhibitory hormone inhibits gonadal development and maintenance by decreasing gonadotropin synthesis and release in male quail. Endocrinology. 2006; 147:1187-1194. [PubMed: 16293662]

82. Ciccone NA, Dunn IC, Boswell T, Tsutsui K, Ubuka T, Ukena K, Sharp PJ. Gonadotrophin inhibitory hormone depresses gonadotrophin alpha and follicle-stimulating hormone beta subunit expression in the pituitary of the domestic chicken. J Neuroendocrinol. 2004; 16:999-1006. [PubMed: 15667455]

83. Ubuka T, Tsutsui K. Gonadotropin-inhibitory hormone inhibits aggressive behavior of male quail by increasing neuroestrogen synthesis in the brain beyond its optimum concentration. Gen Comp Endocrinol. 2014; 205:49-54. [PubMed: 24698787]

84. Bentley GE, Perfito N, Ukena K, Tsutsui K, Wingfield JC. Gonadotropin-inhibitory peptide in song sparrows (Melospiza melodia) in different reproductive conditions, and in house sparrows (Passer domesticus) relative to chicken-gonadotropin-releasing hormone. J Neuroendocrinol. 2003; 15:794-802. [PubMed: 12834441]

85. Rizwan MZ, Porteous R, Herbison AE, Anderson GM. Cells expressing RFamide-related peptide-1/3, the mammalian gonadotropin-inhibitory hormone orthologs, are not hypophysiotropic neuroendocrine neurons in the rat. Endocrinology. 2009; 150:1413-1420. [PubMed: 19008316]

86. Anderson GM, Relf HL, Rizwan MZ, Evans JJ. Central and peripheral effects of RFamide-related peptide-3 on luteinizing hormone and prolactin secretion in rats. Endocrinology. 2009; 150:18341840. [PubMed: 19022888]

87. Ubuka T, Kim S, Huang YC, Reid J, Jiang J, Osugi T, Chowdhury VS, Tsutsui K, Bentley GE. Gonadotropin-inhibitory hormone neurons interact directly with gonadotropin-releasing hormone-I and -II neurons in European starling brain. Endocrinology. 2008; 149:268-278. [PubMed: 17901228]

88. Kriegsfeld LJ, Mei DF, Bentley GE, Ubuka T, Mason AO, Inoue K, Ukena K, Tsutsui K, Silver R. Identification and characterization of a gonadotropin-inhibitory system in the brains of mammals. Proc Natl Acad Sci USA. 2006; 103:2410-2415. [PubMed: 16467147]

89. Ukena K, Ubuka T, Tsutsui K. Distribution of a novel avian gonadotropin-inhibitory hormone in the quail brain. Cell Tissue Res. 2003; 312:73-79. [PubMed: 12712318]

90. Ubuka T, Morgan K, Pawson AJ, Osugi T, Chowdhury VS, Minakata H, Tsutsui K, Millar RP, Bentley GE. Identification of human GnIH homologs, RFRP-1 and RFRP-3, and the cognate receptor, GPR147 in the human hypothalamic pituitary axis. PLoS ONE. 2009; 4:e8400. [PubMed: 20027225]

91. Ubuka T, Lai H, Kitani M, Suzuuchi A, Pham V, Cadigan PA, Wang A, Chowdhury VS, Tsutsui K, Bentley GE. Gonadotropin-inhibitory hormone identification, cDNA cloning, and distribution in rhesus macaque brain. J Comp Neurol. 2009; 517:841-855. [PubMed: 19844991]

92. Murakami M, Matsuzaki T, Iwasa T, Yasui T, Irahara M, Osugi T, Tsutsui K. Hypophysiotropic role of RFamide-related peptide-3 in the inhibition of LH secretion in female rats. J Endocrinol. 2008; 199:105-112. [PubMed: 18653621]

93. Bentley GE, Kriegsfeld LJ, Osugi T, Ukena K, O’Brien S, Perfito N, Moore IT, Tsutsui K, Wingfield JC. Interactions of gonadotropin-releasing hormone $(\mathrm{GnRH})$ and gonadotropininhibitory hormone $(\mathrm{GnIH})$ in birds and mammals. J Exp Zool A Comp Exp Biol. 2006; 305:807814. [PubMed: 16902963]

94. Smith JT, Coolen LM, Kriegsfeld LJ, Sari IP, Jaafarzadehshirazi MR, Maltby M, Bateman K, Goodman RL, Tilbrook AJ, Ubuka T, Bentley GE, Clarke IJ, Lehman MN. Variation in kisspeptin and RFamide-related peptide (RFRP) expression and terminal connections to gonadotropinreleasing hormone neurons in the brain: a novel medium for seasonal breeding in the sheep. Endocrinology. 2008; 149:5770-5782. [PubMed: 18617612]

95. Mason AO, Duffy S, Zhao S, Ubuka T, Bentley GE, Tsutsui K, Silver R, Kriegsfeld LJ. Photoperiod and reproductive condition are associated with changes in RFamide-related peptide (RFRP) expression in Syrian hamsters (Mesocricetus auratus). J Biol Rhythms. 2010; 25:176-185. [PubMed: 20484689] 
96. Piekarski DJ, Jarjisian SG, Perez L, Ahmad H, Dhawan N, Zucker I, Kriegsfeld LJ. Effects of pinealectomy and short day lengths on reproduction and neuronal RFRP-3, Kisspeptin, and GnRH in female Turkish hamsters. J Biol Rhythms. 2014; 29:181-191. [PubMed: 24916391]

97. Ubuka T, Inoue K, Fukuda Y, Mizuno T, Ukena K, Kriegsfeld LJ, Tsutsui K. Identification, expression, and physiological functions of Siberian hamster gonadotropin-inhibitory hormone. Endocrinology. 2012; 153:373-385. [PubMed: 22045661]

98. Ubuka T, Bentley GE, Ukena K, Wingfield JC, Tsutsui K. Melatonin induces the expression of gonadotropin-inhibitory hormone in the avian brain. Proc Natl Acad Sci USA. 2005; 102:30523057. [PubMed: 15708982]

99. Chowdhury VS, Yamamoto K, Ubuka T, Bentley GE, Hattori A, Tsutsui K. Melatonin stimulates the release of gonadotropin-inhibitory hormone by the avian hypothalamus. Endocrinology. 2010; 151:271-280. [PubMed: 19952272]

100. Calisi RM, Diaz-Munoz SL, Wingfield JC, Bentley GE. Social and breeding status are associated with the expression of GnIH. Genes Brain Behav. 2011; 10:557-564. [PubMed: 21466656]

101. Calisi RM, Rizzo NO, Bentley GE. Seasonal differences in hypothalamic EGR-1 and GnIH expression following capture-handling stress in house sparrows (Passer domesticus). Gen Comp Endocrinol. 2008; 157:283-287. [PubMed: 18571170]

102. McGuire NL, Koh A, Bentley GE. The direct response of the gonads to cues of stress in a temperate songbird species is season-dependent. PeerJ. 2013; 1:e139. [PubMed: 24024084]

103. McGuire NL, Kangas K, Bentley GE. Effects of melatonin on peripheral reproductive function: regulation of testicular GnIH and testosterone. Endocrinology. 2011; 152:3461-3470. [PubMed: 21771888]

104. McGuire NL, Bentley GE. Neuropeptides in the gonads: from evolution to pharmacology. Front Pharmacol. 2010; 1:114. [PubMed: 21607065]

105. McGuire NL, Bentley GE. A functional neuropeptide system in vertebrate gonads: gonadotropininhibitory hormone and its receptor in testes of field-caught house sparrow (Passer domesticus). Gen Comp Endocrinol. 2010; 166:565-572. [PubMed: 20074575]

106. Bentley GE, Ubuka T, McGuire NL, Chowdhury VS, Morita Y, Yano T, Hasunuma I, Binns M, Wingfield JC, Tsutsui K. Gonadotropin-inhibitory hormone and its receptor in the avian reproductive system. Gen Comp Endocrinol. 2008; 156:34-43. [PubMed: 18031743]

107. Zhao S, Zhu E, Yang C, Bentley GE, Tsutsui K, Kriegsfeld LJ. RFamide-related peptide and messenger ribonucleic acid expression in mammalian testis: association with the spermatogenic cycle. Endocrinology. 2010; 151:617-627. [PubMed: 20051487]

108. Oishi H, Klausen C, Bentley GE, Osugi T, Tsutsui K, Gilks CB, Yano T, Leung PC. The human gonadotropin-inhibitory hormone ortholog RFamide-related peptide-3 suppresses gonadotropininduced progesterone production in human granulosa cells. Endocrinology. 2012; 153:34353445. [PubMed: 22691551]

109. Kirby ED, Geraghty AC, Ubuka T, Bentley GE, Kaufer D. Stress increases putative gonadotropin inhibitory hormone and decreases luteinizing hormone in male rats. Proc Natl Acad Sci USA. 2009; 106:11324-11329. [PubMed: 19541621]

110. Geraghty AC, Muroy SE, Zhao S, Bentley GE, Kriegsfeld LJ, Kaufer D. Knockdown of hypothalamic RFRP3 prevents chronic stress-induced infertility and embryo resorption. Elife. 2015; 4:e04316.doi: 10.7554/eLife.04316

111. Dickens MJ, Bentley GE. Stress, captivity, and reproduction in a wild bird species. Horm Behav. 2014; 66:685-693. [PubMed: 25257808]

112. Lynn SE, Perfito N, Guardado D, Bentley GE. Food, stress, and circulating testosterone: cue integration by the testes, not the brain, in male zebra finches (Taeniopygia guttata). Gen Comp Endocrinol. 2015; 215:1-9. [PubMed: 25849310]

113. Ernst DK, Lynn SE, Bentley GE. Differential response of GnIH in the brain and gonads following acute stress in a songbird. Gen Comp Endocrinol. 2016; 227:51-57. [PubMed: 26158243]

114. Lopes PC, Wingfield JC, Bentley GE. Lipopolysaccharide injection induces rapid decrease of hypothalamic GnRH mRNA and peptide, but does not affect GnIH in zebra finches. Horm Behav. 2012; 62:173-179. [PubMed: 22789464] 
115. Simoni M, Gromoll J, Nieschlag E. The follicle-stimulating hormone receptor: biochemistry, molecular biology, physiology, and pathophysiology. Endocr Rev. 1997; 18:739-773. [PubMed: 9408742]

116. Dufau ML. The luteinizing hormone receptor. Annu Rev Physiol. 1998; 60:461-496. [PubMed: 9558473]

117. Tena-Sempere M. Explorin the role of ghrelin as a novel regulator of gonadal function. Growth Horm IGF Res. 2005; 15:83-88. [PubMed: 15809012]

118. Mayerhofer, A. Leydig cell regulation by catecholamines and neuroendocrine messengers. In: Payne, AH.; Hardy, MP.; Russell, LD., editors. The Leydig Cell. Cache River Press; St Louis, MO: 1996. p. 407-417.

119. McGuire NI, Bentley GE. Neuropeptides in the gonads: from evolution to pharmacology. Front Pharmacol. 2010; 1:1-13. [PubMed: 21607058]

120. Teerds KJ, Dorrington JH. Localization of transforming growth factor beta1 and beta2 during testicular development in the rat. Biol Reprod. 1993; 48:40-45. [PubMed: 8418916]

121. Wang X, Shen CL, Dyson MT, Eimerl S, Orly J, Hutson JC, Stocco DM. Cyclooxygenase-2 regulation of the age-related decline in testosterone biosynthesis. Endocrinology. 2005; 146:4202-4208. [PubMed: 16002525]

122. Tinajero JC, Fabri A, Ciocca DR, Dufau ML. Serotonin secretion from rat Leydig cells. Endocrinology. 1993; 133:3026-3029. [PubMed: 8243331]

123. Valenti S, Thellung S, Florio T, Guisti M, Schettini G, Giordano G. A novel mechanism for the melatonin inhibition of testosterone secretion by rat Leydig cells: reduction of GnRH-induced increase in cytosolic Ca2+ J Mol Endocrinol. 1999; 23:299-306. [PubMed: 10601975]

124. Dufau ML, Tinajero JC, Fabbri A. Corticotropin-releasing factor: an antireproductive hormone of the testis. FASEB J. 1993; 7:299-307. [PubMed: 8382638]

125. Frungieri MB, Mayerhofer A, Zitta K, Pignataro OP, Calandra RS. Direct effect of melatonin on Syrian hamster testes: melatonin subtype 1a receptors, inhibition of androgen production, and interaction with the local corticotropin-releasing hormone system. Endocrinology. 2005; 146:1541-1552. [PubMed: 15550508]

126. Frungieri MB, Gonzalez-Calvar SI, Rubio M, Ozu M, Lustig L, Calandra RS. Serotonin in golden hamster testes: testicular levels, immunolocalization and role during sexual development and photoperiodic regression-recrudescence transition. Neuroendocrinology. 1999; 69:299-308. [PubMed: 10207282]

127. Frungieri MB, Zitta K, Pignataro OP, Gonzalez-Calvar SI, Calandra RS. Interactions between testicular serotoninergic, catecholaminergic, and corticotropin-releasing hormone systems modulating cAMP and testosterone production in the golden hamster. Neuroendocrinology. 2002; 76:35-46. [PubMed: 12097815]

128. Rossi SP, Matzkin ME, Terradas C, Ponzio R, Puigdomenech E, Levalle O, Calandra RS, Frungieri MB. New insights into melatonin/CRH signaling in hamster Leydig cells. Gen Comp Endocrinol. 2012; 178:153-163. [PubMed: 22580327]

129. Carrillo-Vico A, Calvo JR, Abreu P, Lardone PJ, García-Mauriño S, Reiter RJ, Guerrero JM. Evidence of melatonin synthesis by human lymphocytes and its physiological significance: possible role as intracrine, autocrine, and/or paracrine substance. FASEB J. 2004; 18:537-539. [PubMed: 14715696]

130. Rossi SP, Windschuettl S, Matzkin ME, Terradas C, Ponzio R, Puigdomenech E, Levalle O, Calandra RS, Mayerhofer A, Frungieri MB. Melatonin in testes of infertile men: evidence for anti-proliferative and anti-oxidant effects on local macrophage and mast cell populations. Andrology. 2014; 2:436-449. [PubMed: 24659586]

131. Frungieri MB, Calandra RS, Mayerhofer A, Matzkin ME. Cyclooxygenase and prostaglandins in somatic cell populations of the testes. Reproduction. 2015; 149:R169-R180. [PubMed: 25504871]

132. Matzkin ME, Pelizzari EH, Rossi SP, Calandra RS, Cigorraga SB, Frungieri MB. Exploring the cyclooxygenase 2 (COX2)/15d- $\Delta(12,14)$ PGJ(2) system in hamster Sertoli cells: regulation by FSH/testosterone and relevance to glucose uptake. Gen Comp Endocrinol. 2012; 179:254-264. [PubMed: 22974512] 
133. Frungieri MB, Gonzalez-Calvar SI, Parborell F, Albrecht M, Mayerhofer A, Calandra RS. Cyclooxygenase-2 and prostaglandin F2 alpha in Syrian hamster Leydig cells: inhibitory role on luteinizing hormone/human chorionic gonadotropin-stimulated testosterone production. Endocrinology. 2006; 147:4476-4485. [PubMed: 16740978]

134. Schell C, Frungieri MB, Albrecht M, Gonzalez-Calvar SI, Köhn FM, Calandra RS, Mayerhofer A. A prostaglandin D2 system in the human testis. Fertil Steril. 2007; 88:233-236. [PubMed: 17307169]

135. Brugh VM, Matschke HM, Lipschultz LI. Male factor infertility. Endocrinol Metab Clin North Am. 2003; 32:689-707. [PubMed: 14560894]

136. Wulff C, Wilson H, Largue P, Duncan WC, Armstrong DG, Fraser HM. Angiogenesis in the human corpus luteum: localization and changes in angiopoietins, tie-2, and vascular endothelial growth factor messenger ribonucleic acid. J Clin Endocrinol Metab. 2000; 85:4302-4309. [PubMed: 11095472]

137. Abramovich D, Parborell F, Tesone M. Effect of a vascular endothelial growth factor (VEGF) inhibitory treatment on the folliculogenesis and ovarian apoptosis in gonadotropin-treated prepubertal rats. Biol Reprod. 2006; 75:434-441. [PubMed: 16775226]

138. Parborell F, Abramovich D, Tesone M. Intrabursal administration of the antiangiopoietin 1 antibody produces a delay in rat follicular development associated with an increase in ovarian apoptosis mediated by changes in the expression of BCL2 related genes. Biol Reprod. 2008; 78:506-513. [PubMed: 17989359]

139. Abramovich D, Irusta G, Parborell F, Tesone M. Intrabursal injection of vascular endothelial growth factor trap in ECG-treated prepubertal rats inhibits proliferation and increases apoptosis of follicular cells involving the PI3K/AKT signaling pathway. Fertil Steril. 2010; 93:1369-1377. [PubMed: 19328472]

140. Irusta G, Abramovich D, Parborell F, Tesone M. Direct survival role of vascular endothelial growth factor (VEGF) on rat ovarian follicular cells. Mol Cell Endocrinol. 2010; 325:93-100. [PubMed: 20417686]

141. Hernandez F, Peluffo MC, Stouffer RL, Irusta G, Tesone M. Role of the DLL4-NOTCH system in PGF2alpha-induced luteolysis in the pregnant rat. Biol Reprod. 2011; 84:859-865. [PubMed: 21209419]

142. Kopan R, Ilagan MX. The canonical notch signaling pathway: unfolding the activation mechanism. Cell. 2009; 137:216-233. [PubMed: 19379690]

143. Accialini P, Hernandez SF, Bas D, Pazos MC, Irusta G, Abramovich D, Tesone M. A link between notch and progesterone maintains the functionality of the rat corpus luteum. Reproduction. 2015; 149:1-10. [PubMed: 25433026]

144. Pinilla L, Aguilar E, Dieguez C, Millar RP, Tena-Sempere M. Kisspeptins and reproduction: physiological roles and regulatory mechanisms. Physiol Rev. 2012; 92:1235-1316. [PubMed: 22811428]

145. Vikman J, Ahrén BD. Inhibitory effect of kisspeptins on insulin secretion from isolated mouse islets. Diabetes Obes Metab. 2009; (Suppl 4):197-201. [PubMed: 19817802]

146. Castellano JM, Gaytan M, Roa J, Vigo E, Navarro VM, Bellido C, Dieguez C, Aguilar E, Sanchez-Criado JE, Pellicer A, Pinilla L, Gaytan F, Tena-Sempere M. Expression of KiSS-1 in rat ovary: putative local regulator of ovulation? Endocrinology. 2006; 147:4852-4862. [PubMed: 16825322]

147. Ricu M, Ramirez VD, Paredes AH, Lara HE. Evidence for a celiac ganglion-ovarian kisspeptin neural network in the rat: intraovarian anti-kisspeptin delays vaginal opening and alters estrous cyclicity. Endocrinology. 2012; 153:4966-4977. [PubMed: 22869347]

148. Laoharatchatathanin T, Terashima R, Yonezawa T, Kurusu S, Kawaminami M. Augmentation of Metastin/Kisspeptin mRNA expression by the proestrous luteinizing hormone surge in granulosa cells of rats: implications for luteinization. Biol Reprod. 2015; 93:15. [PubMed: 25995272]

149. Fernandois D, Na E, Cuevas F, Cruz G, Lara HE, Paredes AH. Kisspeptin is involved in ovarian follicular development during the fertility and subfertility periods of rats. J Endocrinol. 2016; 228:161-170. [PubMed: 26698566] 
150. Gaytán F, Gaytán M, Castellano JM, Romero M, Roa J, Aparicio B, Garrido N, Sánchez-Criado JE, Millar RP, Pellicer A, Fraser HM, Tena-Sempere M. KiSS-1 in the mammalian ovary: distribution of kisspeptin in human and marmoset and alterations in KiSS-1 mRNA levels in a rat model of ovulatory dysfunction. Am J Physiol Endocrinol Metab. 2009; 296:520-531.

151. Xiao Y, Ni Y, Huang Y, Wu J, Grossmann R, Zhao R. Effects of kisspeptin-10 on progesterone secretion in cultured chicken ovarian granulosa cells from preovulatory (F1-F3) follicles. Peptides. 2011; 32:2091-2097. [PubMed: 21924307]

152. Peng J, Tang M, Zhang BP, Zhang P, Zhong T, Zong T, Yang B, Kuang HB. Kisspeptin stimulates progesterone secretion via the Erk1/2 mitogen-activated protein kinase signaling pathway in rat luteal cells. Fertil Steril. 2013; 99:1436-1443. [PubMed: 23312234]

153. Cedars MI. Biomarkers of ovarian reserve-do they predict somatic aging? Semin Reprod Med. 2013; 31:443-451. [PubMed: 24101225]

154. Hoyer PB. Damage to ovarian development and function. Cell Tissue Res. 2005; 322:99-106. [PubMed: 15856308]

155. Lenton EA, Deketser DM, Woodward AJ. Inhibin concentrations throughout the menstrual cycle of normal, infertile and older women compared with those during spontaneous conceptions cycles. J Clin Endocrinol Metab. 1991; 73:1180-1186. [PubMed: 1955499]

156. Semenova II. Adrenergic innervation of ovaries in Stein-Leventhal syndrome. Vestn Akad Med Nauk SSSR. 1969; 24:58-62.

157. Heider U, Pedal I, Spanel-Borowski K. Increase in nerve fibers and loss of mast cells in polycystic and postmenopausal ovaries. Fertil Steril. 2001; 75:1141-1147. [PubMed: 11384640]

158. Acuña E, Fornes R, Fernandois D, Garrido MP, Greiner M, Lara HE, Paredes AH. Increases in norepinephrine release and ovarian cyst formation during ageing in the rat. Reprod Biol Endocrinol. 2009; 7:64. [PubMed: 19531218]

159. Chavez-Genaro R, Lombide P, Dominguez R, Rosas P, Vazquez-Cuevas F. Sympathetic pharmacological denervation in ageing rats: effects on ovulatory response and follicular population. Reprod Fertil Dev. 2007; 19:954-960. [PubMed: 18076827]

160. Cooke BM, Woolley CS. Sexually dimorphic synaptic organization of the medial amygdala. J Neurosci. 2005; 25:10759-10767. [PubMed: 16291949]

161. Matsumoto A, Arai Y. Development of sexual dimorphism in synaptic organization in the ventromedial nucleus of the hypothlamus in rats. Neurosci Lett. 1986; 68:165-168. [PubMed: 3748448]

162. Christensen A, Dewing P, Micevych P. Membrane-initiated estradiol signaling induces spinogenesis required for female sexual receptivity. J Neurosci. 2011; 31:17583-17589. [PubMed: 22131419]

163. Akama KT, Thompson LI, Milner TA, McEwen BS. Post-synaptic density-95 (PSD-95) binding capacity of G-protein-coupled receptor 30 (GPR30), an estrogen receptor that can be identified in hippocampal dendritic spines. J Biol Chem. 2013; 288:6438-6450. [PubMed: 23300088]

164. Waters EM, Thompson LI, Patel P, Gonzales AD, Ye HZ, Filardo EJ, Clegg DJ, Gorecka J, Akama KT, McEwen BS, Milner TA. G-protein-coupled estrogen receptor 1 is anatomically positioned to modulate synaptic plasticity in the mouse hippocampus. J Neurosci. 2015; 35:2384-2397. [PubMed: 25673833]

165. Garcia, BL.; Mana, A.; Kim, A.; Sinchak, K. Antagonism of Estrogen Receptors Facilitates Sexual Receptivity through Opioid Circuits in the Arcuate Nucleus of the Hypothalamus and the Medial Preoptic Nucleus in Estradiol Primed Non-Receptive Female Rats. Society for Neuroscience; San Diego, CA: 2010.

166. Kuo J, Hamid N, Bondar G, Prossnitz E, Micevych P. Membrane estrogen receptors stimulate intracellular calcium release and progesterone synthesis in hypothalamic astrocytes. J Neurosci. 2010; 30:12950-12957. [PubMed: 20881113]

167. Qiu J, Ronnekleiv O, Kelly M. Modulation of hypothalamic neuronal activity through a novel Gprotein-coupled estrogen membrane receptor. Steroids. 2008; 73:985-991. [PubMed: 18342349]

168. Qui J, Bosch M, Tobias S, Grandy D, Scanlan T, Ronnekleiv O, Kelly M. Rapid signaling of estrogen in hypothalamic neurons involves a novel G-protein-coupled estrogen receptor that activates protein kinase C. J Neurosci. 2003; 23:9529-9540. [PubMed: 14573532] 
169. Christensen A, Micevych P. A novel membrane estrogen receptor activated by STX induces female sexual receptivity through an interacation with mGluR1a. Neuroendocrinology. 2013; 97:363-368. [PubMed: 23571598]

170. Nishida H, Okabe S. Direct astrocytic contacts regulate local maturation of dendritic spines. J Neurosci. 2007; 27:331-340. [PubMed: 17215394]

171. Liu T, Kong D, Shah BP, Ye C, Koda S, Saunders A, Ding JB, TYang Z, Sabatini BL, Lowell BB. Fasting activation of AgRP neurons requires NMDA receptors and involves spinogenesis and increased excitatory tone. Neuron. 2012; 73:511-522. [PubMed: 22325203]

172. Mills RH, Sohn RK, Micevych PE. Estrogen-induced mu-opioid receptor internalization in the medial preoptic nucleus is mediated via neuropeptide Y-Y1 receptor activation in the arcuate nucleus of female rats. J Neurosci. 2004; 24:947-955. [PubMed: 14749439]

173. Kasai H, Matsuzaki M, Noguchi J, Yasumatsu N, Nakahara H. Structure-stability-function relationships of dendritic spines. Trends Neurosci. 2003; 26:360-368. [PubMed: 12850432] 


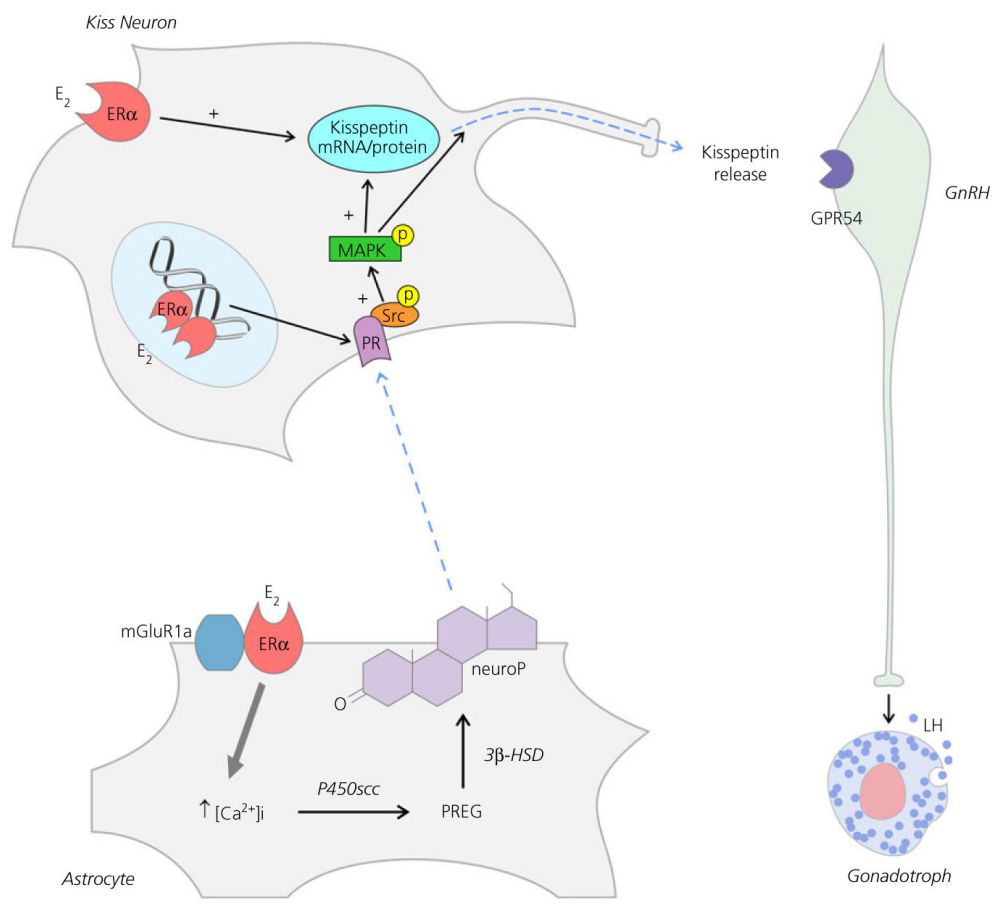

Fig. 1.

A model showing proposed actions of oestradiol $\left(\mathrm{E}_{2}\right)$ on hypothalamic cells. In kisspeptin (Kiss1) neurones, $E_{2}$ acts at both membrane and nuclear oestrogen receptors. During dioestrus, classical nuclear $\mathrm{E}_{2}$ signalling induces progesterone receptor (PR) expression in Kiss1 neurones in the rostral periventricular nucleus of the third ventricle (RP3V). On prooestrus, rising $\mathrm{E}_{2}$ leads to transactivation of mGluR1a in astrocytes, which increases $\left[\mathrm{Ca}^{2+}\right]_{\mathrm{i}}$, leading to the conversion of cholesterol to pregnenolone (PREG) by the P450scc enzyme and the conversion of PREG to progesterone (neuroP) by $3 \beta$-hydroxysteroid dehydrogenase (HSD). Simultaneously, $\mathrm{E}_{2}$ activates an oestrogen receptor (ER)a-mGluR1a complex in neurones leading to the expression of Kiss1. Newly synthesised neuroP diffuses out of the astrocytes and activates $\mathrm{E}_{2}$-induced PR, which has been trafficked to the Kiss1 neuronal membrane. This leads to a series of events culminating in Kiss1 secretion onto GPR54 expressing gonadotrophin-releasing hormone $(\mathrm{GnRH})$ neurones. Signalling through $\mathrm{PR}$ in Kiss1 neurones induces Kiss1 release, activating GnRH neurones and triggering the $\mathrm{E}_{2}$ induced luteinising hormone (LH) surge from anterior pituitary gonadotrophs. MAPK, mitogen-activated protein kinase. 


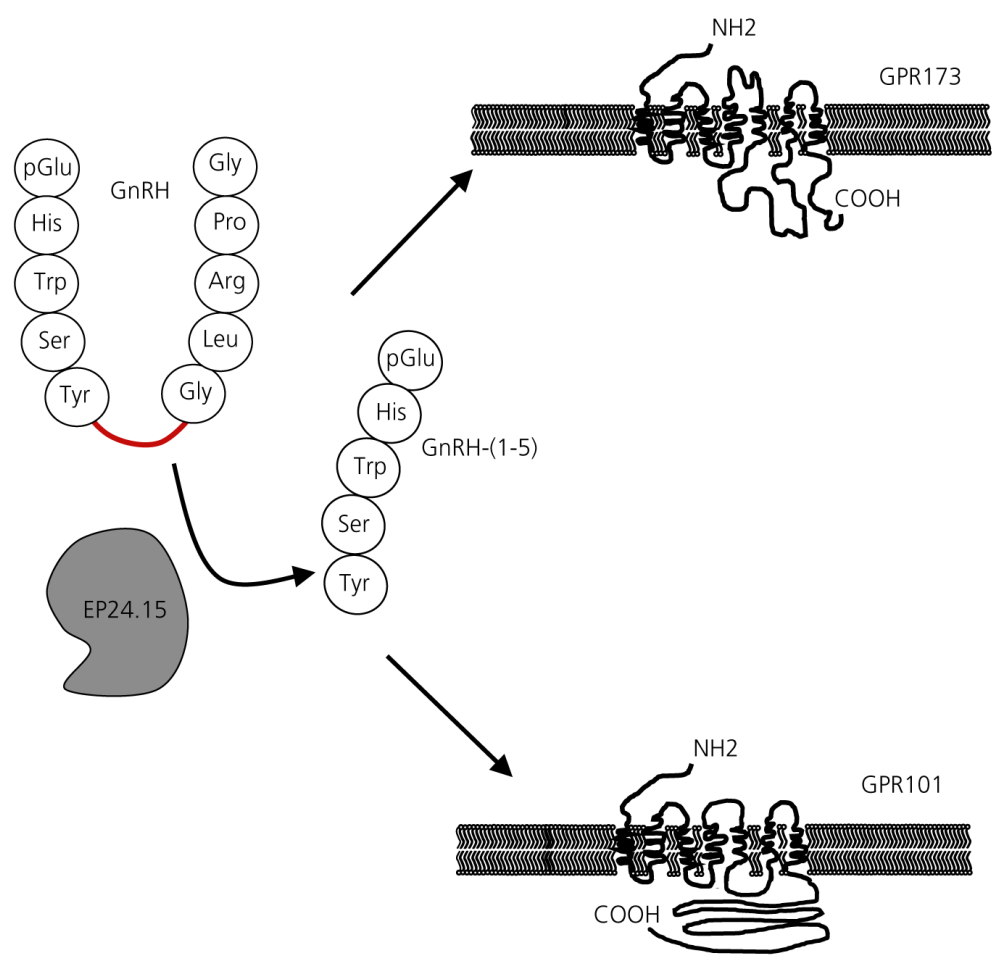

Fig. 2.

Gonadotropin-Releasing Hormone $(\mathrm{GnRH})$ peptide processing and action. The decapeptide, $\mathrm{GnRH}$, is processed extracellularly to form the metabolite, GnRH-(1-5) by the zinc metalloendopeptidase, EC3.4.24.15 (EP24.15; 66, 73). The metabolite, GnRH-(1-5), exerts is biological activities via 2 putative receptors, the G-protein coupled receptors (GPR) GPR101 and GPR173 (70, 71). 